\title{
Hikmah dan Nilai-nilai Pendidikan Adanya Ayat-ayat Muhkamat dan Mutasyabihat dalam Al-Qur'an
}

\author{
Diah Rusmala Dewi ${ }^{1} \&$ Ghamal Sholeh Hutomo ${ }^{2}$ \\ Universitas Islam Negeri Sunan Kalijaga Yogyakarta \\ 1diahrd95@gmail.com \\ 22hamallizers@gmail.com
}

\begin{abstract}
This study aims to analyze the wisdom and educational values of the verses of Mubkamat and Mutasyabibat in the Qur'an. The method used in this research is library research where the writer tries to find, compile and analyze various information through various related sources. The Qur'an has functions as a bayan (explanatory) and budan (guidance) which contains an explicit verse or mubkam. Besides, it also has functions as the greatest miracle and literary book in buman bistory which contains an implicit verse or mutasyabih that will never end to be studied and researched. Mubkamat and mutasyabihat verses are two complementary things in the Qur'an. There is an immeasurable wisdom and educational value for both. Therefore, in learning and understanding both is as well as learning the wisdom of decreasing the Qur'an itself.
\end{abstract}

Keywords: Al-Qur'an, Mubkam, Mutasyabih, Wisdom, Educational Values

\begin{abstract}
Abstrak: Penelitian ini bertujuan untuk menganalisis tentang hikmah dan nilai-nilai pendidikan adanya ayat-ayat muhkamat dan mutasyabihat dalam al-Qur'an. Metode yang digunakan dalam penelitian ini adalah studi pustaka dimana penulis berusaha menemukan, menyusun dan menganalisis berbagai informasi melalui berbagai sumber terkait. Al-Qur'an berfungsi sebagai bayan (penjelas) dan hudan (petunjuk) dimana didalamnya memuat ayat yang tersurat atau muhkam. Selain itu, al-Qur'an juga berfungsi sebagai mukjizat dan kitab sastra terbesar sepanjang sejarah manusia dimana didalamnya memuat ayat yang tersirat atau mutasyabih yang tidak akan habishabisnya untuk dikaji dan diteliti. Ayat-ayat muhkamat dan mutasyabihat adalah dua hal yang saling melengkapi dalam al-Qur'an. Terdapat hikmah dan nilai-nilai pendidikan yang tidak terkira di dalam keduanya. Karena itu, mempelajari keduanya, sama halnya mempelajari hikmah dari penurunan al-Qur'an itu sendiri.
\end{abstract}

Kata Kunci : Al-Qur'an, Muhkam, Mutasyabih, Hikmah, Nilai-Nilai Pendidikan

Islamika : Jurnal Keislaman dan Ilmu Pendidikan

Volume 2, Nomor 1, Januari 2020; 63-83

https:// ejournal.stitpn.ac.id/index.php/islamika 


\section{PENDAHULUAN}

Allah menurunkan al-Qur'an kepada hamba-Nya agar ia menjadi pemberi peringatan bagi semesta alam. Melalui ayat-ayat yang keterangannya tegas dan ciricirinya jelas, Allah menetapkan bagi umat manusia pokok-pokok agama untuk menyelamatkan akidah mereka dan menerangkan jalan lurus yang harus mereka tempuh. Ayat-ayat tersebut adalah Ummul Kitab yang tidak diperselisihkan lagi pemahamannya demi menyelamatkan umat Islam dan menjaga eksistensinya. ${ }^{1}$

Berdasarkan hal tersebut, al-Qur'an memuat apa yang dibutuhkan dalam seluruh aspek kehidupan manusia, baik dalam urusan dunia maupun akhirat yang tujuan utamanya adalah sebagai petunjuk bagi manusia dan sebagai pembeda antara yang haq dan yang batil. Meski demikian, tidak semua ayat-ayat yang terdapat dalam al-Qur'an langsung dapat dipahami oleh manusia atau muhkam yaitu hanya mempunyai makna tunggal saja, melainkan ada pula yang mutasyabih, dimana untuk dapat mengetahui maksud penurunannya, ayat-ayatnya perlu ditakwilkan.

Namun demikian, terdapat perbedaan pendapat di kalangan umat Islam terkait pentakwilan tersebut, dimana tidak semuanya sepakat mengenai kebolehan menafsirkan ayat-ayat yang mutasyabihat tersebut atau dengan kata lain melarangnya. Namun, dibalik kontroversi yang timbul akibat perbedaan pendapat tersebut, justru mengantarkan pada pemahaman terkait hikmah yang dapat dipetik pelajarannya dalam kehidupan manusia. Sebab, seperti yang diketahui bahwa Allah tidaklah menciptakan segala sesuatu itu sia-sia. Karena itu, mencari hikmah untuk menyingkap nilai-nilai pendidikan dari keberadaan ayat-ayat yang muhkam dan mutasyabih dalam al-Qur'an menjadi suatu hal yang penting.

Untuk memahami hal tersebut, maka terlebih dahulu kita harus memahami apa itu muhkam dan mutasyabih, kemudian bagaimana kriteria dan pembagian ayatayat muhkamat dan mutasyabihat, serta bagaimana pendapat para ulama dalam menyikapinya. Sehingga dapat ditarik kesimpulan terkait hikmah serta nilai-nilai pendidikan akan keberadaan ayat muhkam dan mutasyabih dalam Al-Qur'an yang dapat dijadikan pelajaran bagi manusia, dimana kesemuanya tersebut akan diuraikan

${ }^{1}$ Manna' Khalil Al-Qattan, Studi Ilmu-Ilmu Qur'an; diterjemahkan dari bahasa Arab oleh Mudzakir, (Jakarta: PT Pustaka Litera Antar Nusa, 2009), hal. 302. 
dalam pembahasan ini yang diharapankan dapat membantu kita dalam memahami kajian tentang muhkam dan mutasyabih.

\section{METODE}

Jenis penelitian yang digunakan dalam penelitian ini adalah pendekatan studi pustaka atau library research. Dimana penelitian kepustakaan tidak terjun langsung ke lapangan, atau dengan kata lain jenis penelitian kualitatif dengan mengumpulkan, menganalisis, mengolah dan menyajikan buku, jurnal dan teksteks yang berhubungan dengan tema penelitian sebagai bahan referensi dalam bentuk laporan kepustakaan. ${ }^{2}$

Penulis berusaha menemukan dan menyusun berbagai informasi tentang hikmah dan nilai-nilai pendidikan adanya ayat-ayat muhkamat dan mutasyabihat dalam al-Qur'an melalui berbagai sumber buku terkait, baik buku primer maupun sekunder.

\section{PEMBAHASAN}

A. Pengertian Muhkam dan Mutasyabih

Mubkam secara bahasa berasal dari kata hakama. Kata bukm berarti memutuskan antara dua hal atau lebih perkara, maka hakim adalah orang yang mencegah yang zalim dan memisahkan dua pihak yang sedang bertikai. Mubkam adalah sesuatu yang dikokohkan, jelas, fasih dan membedakan antara yang hak dan batil. ${ }^{3}$

Sedangkan, mutasyabih secara bahasa berasal dari kata syabaha, yakni bila salah satu dari dua hal serupa dengan yang lain. Syubhab ialah keadaan di mana satu dari dua hal itu tidak dapat dibedakan dari yang lain karena adanya kemiripan di antara keduanya secara konkrit atau abstrak. ${ }^{4}$

${ }^{2}$ Mestika Zed, Metode Penelitian Kepustakaan, (Jakarta: Yayasan Obor Indonesia, 2008), hal. 12

${ }^{3}$ Muhammad Chirzin, Al-Qur'an dan Ulumul Qur'an, (Yogyakata: PT Dana Bhakti Prima Yasa, 1998), hal. 70.

${ }^{4}$ Ibid., hal. 70 . 
Selain pengertian berdasarkan bahasa (etimologi), adapun secara terminologi (istilah), muhkam dan mutasyabih seperti yang diungkapkan oleh para ulama adalah sebagai berikut:

1. Kelompok ahlussunnah berpendapat bahwa ayat-ayat muhkam adalah ayat yang baik melalui takwil (metafora) ataupun tidak, maksudnya dapat diketahui dengan gamblang, Sementara itu, ayat-ayat mutasyabih adalah ayat yang maksudnya hanya dapat diketahui oleh Allah, seperti saat kedatangan hari kiamat, keluarnya Dajjal, dan huruf-huruf muqaththa'ah.

2. Ayat-ayat muhkam adalah ayat yang maknanya jelas, sedangkan ayat-ayat mutasyabih sebaliknya.

3. Ibn 'Abbas mendefinisikan ayat-ayat muhkam sebagai ayat yang tidak memunculkan kemungkinan sisi arti lain, sedangkan ayat-ayat mutasyabih yaitu ayat yang mempunyai kemungkinan sisi arti banyak.

4. Al-Mawardi mengemukakan bahwa ayat-ayat muhkam adalah ayat yang maknanya dapat dipahami akal, seperti bilangan rakaat shalat, kekhususan bulan Ramadhan untuk pelaksanaan puasa wajib, sedangkan ayat-ayat mutasyabih sebaliknya.

5. Ayat-ayat muhkam adalah ayat yang dapat berdiri sendiri (dalam pemaknaannya), sedangkan ayat-ayat mutasyabih bergantung pada ayat lain.

6. Ayat-ayat muhkam adalah ayat yang tanpa pentakwilan, maksudnya segera dapat diketahui, sedangkan ayat-ayat mutasyabih memerlukan pentakwilan untuk mengetahui maksudnya.

7. Ayat-ayat muhkam adalah ayat yang berbicara tentang kefarduan, ancaman, dan janji, sedangkan ayat-ayat mutasyabih berbicara tentang kisah-kisah dan perumpamaan-perumpamaan. ${ }^{5}$

Muhkam adalah kata yang dipakai oleh Al-Qur'an untuk menunjuk ayat yang terang makna dan lafalnya yang diletakkan untuk suatu makna yang kuat dan mudah dipahami. Sedangkan mutasyabih adalah kata yang dipakai oleh Al-Qur'an untuk menunjuk ayat yang bersifat global (mujmal) yang membutuhkan ta'wil

${ }^{5}$ Rosihon Anwar, Ulum Al-Qur'an, (Bandung: CV Pustaka Setia, 2007), hal. 121-122. 
(mu'awal) dan sukar dipahami (musykil), sebab ayat-ayat yang mujmal membutuhkan rincian; ayat-ayat yang mu'awal, baru dapat diketahui maknanya setelah dita'wilkan, dan ayat-ayat yang musykil samar maknanya dan sukar dimengerti. ${ }^{6}$

Dari pengertian diatas, dapat disimpulkan bahwa muhkam adalah ayatayat yang maknanya sudah jelas, tidak samar lagi. Adapun mutasyabih adalah ayat-ayat yang maknanya belum jelas sehingga memerlukan pentakwilan untuk mengetahui maksudnya.

B. Ayat-Ayat Muhkamat

Menurut kebanyakan ulama, sebab adanya ayat-ayat muhkamat itu sudah jelas, yakni seperti keterangan pada ayat 1 surah Hud yang artinya: "suatu kitab yang ayat-ayatnya disusun dengan rapi." Juga karena kebanyakan tertib dan susunan ayat-ayat Al-Qur'an itu rapi dan urut, maknanya juga mudah dicerna akal pikiran karena tidak samar artinya sehingga dapat dipahami umat dengan mudah. ${ }^{7}$ Berikut adalah contoh dari ayat yang muhkam: ${ }^{8}$

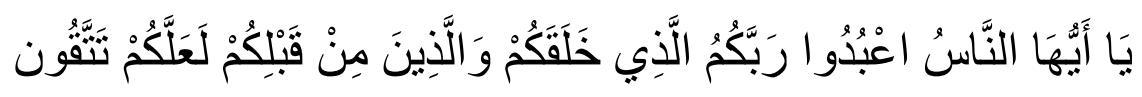

Artinya: "hai manusia, sembahlah tuhanmu yang telah menciptakanmu dan orang-orang sebelum kamu, agar kamu bertakwa". (Al-Baqarah: 21)

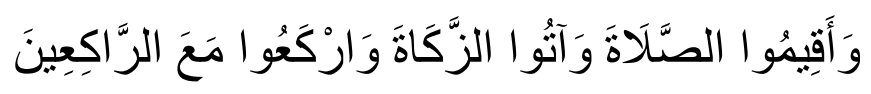

Artinya: "Dan dirikanlah sholat, tunaikanlah zakat dan ruku'lah berserta orangorang yang ruku"'. (QS. al-Baqarah: 43)

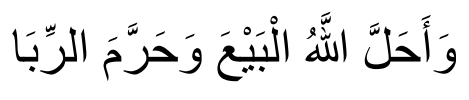

Artinya: "Allah telah menghalalkan jual beli dan mengharamkan riba". (AlBaqarah: 275)

${ }^{6}$ Muhammad Chirzin, Al-Qur'an dan Ulumul Qur'an..., hal 72.

${ }^{7}$ Abdul Djalal, Ulumul Qur'an, (Surabaya: Dunia Ilmu, 2000), hal. 244.

${ }^{8}$ Departemen Agama RI, Al-Qur'an dan Terjemahnya, (Bandung: Alfatih, 2012). 
C. Ayat-Ayat Mutasyabihat

Adapun, adanya ayat-ayat mutasyabihat dalam al-Qur'an secara rinci adalah disebabkan oleh tiga hal yaitu: karena kesamaran pada lafal, pada makna, dan pada lafal dan maknanya. ${ }^{9}$

1. Kesamaran pada lafal

Sebab kesamaran pada lafal ini ada dua macam, sebagai berikut: ${ }^{10}$

a. Kesamaran dalam lafal mufrad

Kesamaran dalam lafal mufrad (lafal yang belum tersusun dalam kalimat) maksudnya yaitu terdapat lafal-lafal mufrad yang artinya tidak jelas, baik disebabkan lafalnya yang gharib (asing), atau musytarak (bermakna ganda).

1) Contoh kesamaran lafal mufrad yang gharib (asing)

Contoh: Q.S. Abasa [80]: 31

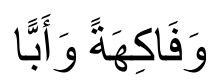

Terjemahan: Dan buah-buahan serta rumput-rumputan.

Lafal أَبٌّ pada ayat tersebut mutasyabih karena jarangnya digunakan, sehingga asing. Kata diartikan rumput-rumputan berdasarkan pemahaman dari ayat berikutnya :

Q.S. Abasa [80]: 32 yang berbunyi:

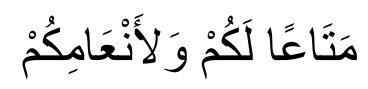

Terjemahan: Untuk kesenanganmu dan untuk binatangbinatang ternakmu. ${ }^{11}$

2) Contoh kesamaran lafal mufrad yang musytarak (bermakna ganda)

Contoh: Q.S. As-Saffat [37]: 93

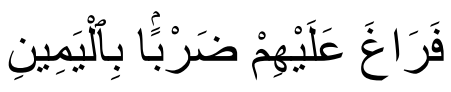

${ }_{9}$ Abdul Djalal, Ulumul Qur'an..., hal. 244.

${ }^{10}$ Ibid., hal. 244.

11 Abdul Djalal, Ulumul Qur'an..., hal. 245. 
Terjemahan: Lalu dihadapinya berhala-berhala itu sambil memukulnya dengan tangan kanannya / dengan kuatnya.

Lafal لَيْمِينِ dalam ayat tersebut adalah lafal mufrad yang musytarak (bermakna ganda). Kata لَيَمِينِ tersebut bisa berarti tangan kanan atau kekuatan. Arti tersebut semuanya relevan untuk kata لَيْمِينِ sehingga mengakibatkan kesamaran. Apakah arti tangan kanan, sehingga ayat itu berarti Nabi Ibahim memukul berhala-berhala itu dengan tangan kanannya, sebab beliau tidak kidal tentunya. Ataukah arti kuat, sehingga ayat itu berarti Nabi Ibrahim memukul berhalaberhala dengan kuat karena berhala-berhala itu kebanyakan terbuat dari batu. ${ }^{12}$

Begitu juga beberapa huruf muqaththa'ah (penggalanpenggalan huruf di pembukaan atau permulaan surah-surah

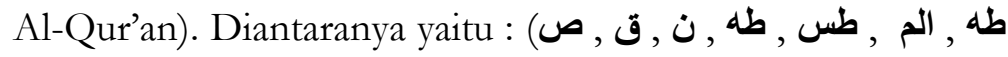
, ( كهيعص (an sebagainya. Maksud dari huruf-huruf tersebut sulit dipahami karena samar maknanya, sehingga menjadikannya termasuk ayat-ayat mutasyabihat karena samar dalam lafalnya. Karena itu, banyak ulama yang hanya والله أعلمُ menafsirkan huruf-huruf tersebut dengan kalimat بالصسواب hanya Allah SWT yang lebih mengetahui maksud pada lafal tersebut). ${ }^{13}$

b. Kesamaran dalam lafal murakkab

Kesamaran dalam lafal murakkab itu disebabkan karena lafal-lafal yang murakkab (lafal yang tersusun dalam kalimat) itu terlalu ringkas, terlalu luas, atau karena susunan kalimatnya kurang tertib.

12 Ibid., hal. 245.

13 Abdul Djalal, Ulumul Qur'an..., hal. 246. 
1) Contoh tasyabuh (kesamaran) dalam lafal murakkab terlalu ringkas. Misalnya firman Allah SWT dalam Q.S. An-Nisa ayat 3:

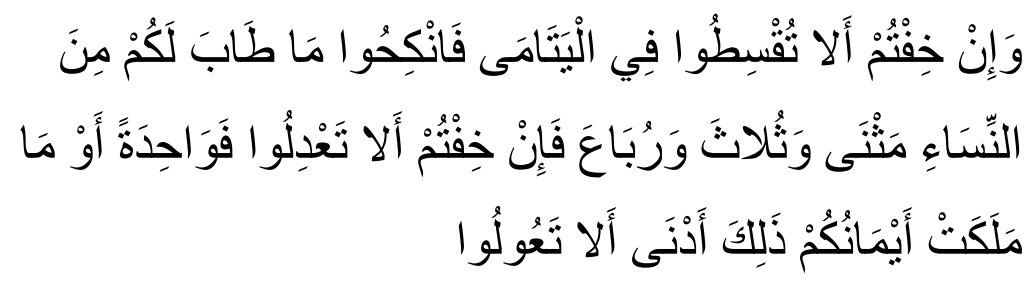

Artinya: "Dan jika kalian takut tidak akan dapat berlaku adil terhadap (hak-hak) perempuan yang yatim (bilamana kamu mengawininya), maka kawinilah wanita-wanita (lain) yang kamu senangi, dua, tiga atau empat“.

Ayat tersebut masih sukar dipahami karena susunan kalimatnya terlalu singkat sehingga membutuhkan keterangan tambahan untuk melengkapinya agar dapat memperjelas maksudnya, yaitu "jika takut tidak dapat berlaku adil terhadap hak istrinya yang yatimah dimana harus dijaga status dan hartanya sebagai anak yatim, maka supaya menikah saja dengan wanita yang tidak yatim dimana lebih bebas sedikit penjagaan terhadap hak-haknya". ${ }^{14}$

2) Contoh kesamaran dalam lafal murakkab karena terlalu luas, seperti pada potongan ayaat 11 Q.S. As-Shura :

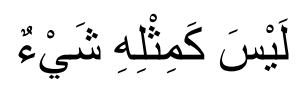

Artinya : tidak ada sesuatu apapun seperti yang seperti-Nya.

Pada ayat tersebut kelebihan huruf kaf dalam kata kamitslibi. Sehingga sulit dimengerti maksudnya. ${ }^{15}$

3) Contoh Kesamaran lafadz murakkab yang tidak tertib susunannya, seperti :

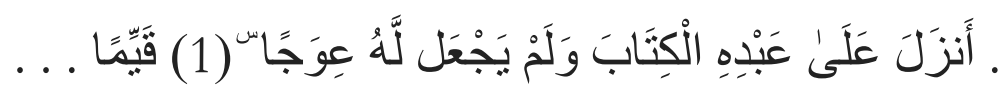


Artinya: Yang telah menurunkan kepada hamba-Nya al-kitab (al-quran) dan Dia tidak mengadakan kebengkokan didalamnya, sebagai bimbingan yang lurus. (QS. Al-Kahfi : 12)

Seandainya susunan kalimat ditertibkan dengan memindahkan kata qayyiman sebelum kata walam yaj'al maka maknanya lebih jelas, seperti :

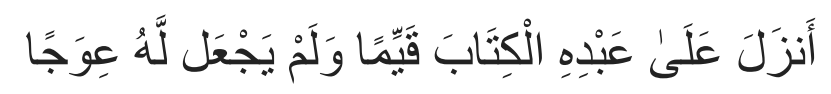

Artinya: Yang telah menurunkan kepada hamba-Nya al-kitab (Al-Quran) sebagai bimbingan yang lurus, dan tidak mengadakan kebengkokan didalamnya. ${ }^{16}$

c. Kesamaran pada makna ayat

Kesamaran itu dikarenakan makna dari lafal-lafalnya tidak terjangkau oleh akal pikiran manusia. Contohnya seperti makna dari sifat-sifat Allah SWT, sifat Qudrat Iradat-Nya, maupun sifat-sifat lainnya. Dan juga termasuk makna dari ihwal hari kiamat, kenikmatan surga, siksa kubur, siksa neraka dan lain sebagainya. ${ }^{17}$ Seperti pada Q.S. Luqman ayat 34, Allah SWT berfirman :

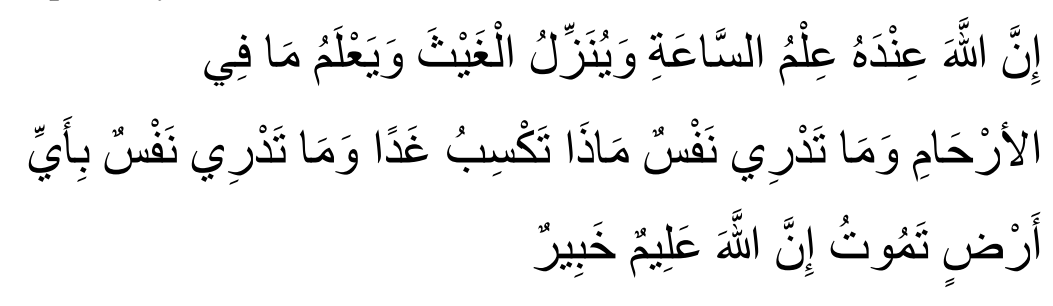

Artinya : "Sesungguhnya hanya Allah sajalah yang memiliki pengetahuan tentang hari kiamat. Dan Dialah yang menurunkan hujan dan mengetahui apa yang ada di dalam rahim. Dan tidak seorangpun yang dapat mengetahui (dengan pasti) apa yang akan diusahakannya besok hari. Dan tiada seorangpun dapat mengetahui di 
bumi mana dia mati. Sesungguhnya Allah Maha Mengetahui lagi Maha Mengenal". ${ }^{18}$

d. Kesamaran pada lafal dan makna ayat

Contohnya pada ayat 189 surah Al-Baqarah:

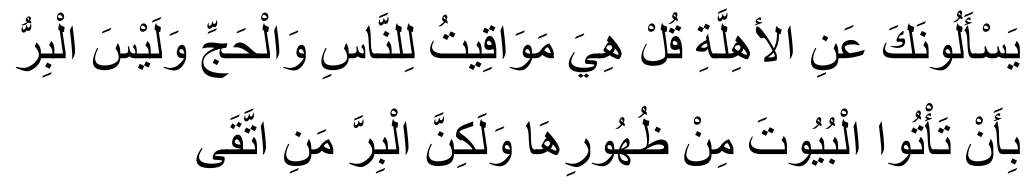

Artinya: "Mereka bertanya kepadamu tentang bulan sabit. Katakanlah:

"Bulan sabit itu adalah tanda-tanda waktu bagi manusia dan (bagi ibadah) haji; Dan bukanlah kebajikan memasuki rumah-rumah dari belakangnya, akan tetapi kebajikan itu ialah kebajikan orang yang bertakwa".

Kesamaran pada ayat tersebut yaitu: pertama, dari lafal terlalu ringkas. Kedua, dari makna tidak jelas yang dimaksud, karena termasuk adat kebiasaan khusus orang arab yang tidak mudah diketahui oleh bangsa lain. Maka akan lebih mudah dipahami, jika ditambah ungkapan,

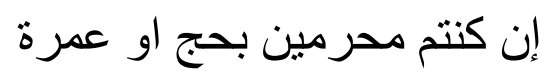

(jika kalian sedang melakukan ihram untuk haji atau umroh). Apalagi jika sudah mengetahui syarat dan rukun ihram, sehingga tidak akan ada masalah baginya. ${ }^{19}$

Para ulama memberikan contoh ayat-ayat muhkam dalam alQur'an dengan ayat-ayat nasikh, ayat-ayat tentang halal, haram, hudud (hukuman), kewajiban, janji dan ancaman. Sementara untuk ayat-ayat mutasyabih mereka mencontohkan dengan ayat-ayat mansukh dan ayat-ayat tentang Asma Allah dan sifat-sifat-Nya, antara lain: ${ }^{20}$

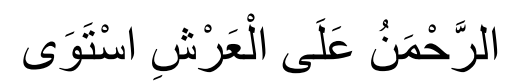

“Ar-rahman bersemayam di atas 'Arsy." (Ta Ha [20]: 5)

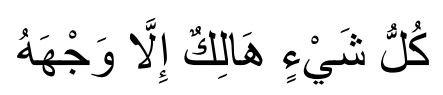

\footnotetext{
${ }^{18}$ Departemen Agama RI, Al-Qur'an dan Terjemahnya, (Bandung: Alfatih, 2012).

${ }^{19}$ Abdul Djalal, Ulumul Qur'an..., hal. 249.

${ }^{20}$ Manna' Khalil Al-Qattan, Studi Ilmu-Ilmu Qur'an..., hal. 306-307.
} 
“Segala sesuatu pasti binasa kecuali wajah-Nya." (al-Qasas [28]: 88)

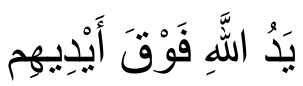

"Tangan Allah di atas tangan mereka." (al-Fatah [48]: 10)

\section{وَهُوَ الْقَاهِرْ فَوْقَ عِبَادِهِ}

"Dan dialah yang berkuasa di atas hamba-hamba-Nya." (al-An'am [6]:

18)

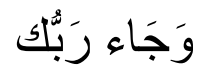

"Dan datanglah Tuhanmu." (al-Fajr [89]: 22)

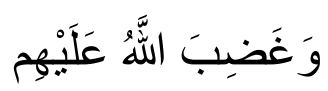

"Dan Allah memarahi mereka." (al-Fath [48]: 6)

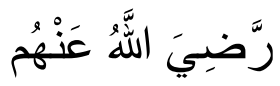

“Allah rida terhadap mereka.” (al-Bayyinah [98]: 8)

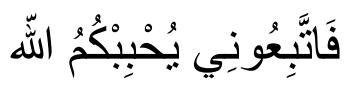

"Maka ikutlah aku, niscaya Allah akan mencintaimu." (Ali Imron [3]:

(31). Dan masih banyak lagi ayat muhkamat dan mutasyabihat yang lainnya.

Beberapa contoh ayat al-Quran diatas menunjukkan bahwa di dalam al-Quran terdapat lafaz-lafaz mutasyabih yang maknamaknanya seakan serupa dengan makna yang kita ketahui dalam kehidupan di dunia tetapi pada hakikatnya kata-kata tersebut tidaklah sama dengan makna yang diketahui manusia. Misalnya kata "bersemayam, wajah Allah, tangan Allah, diatas hambanya" meskipun serupa dengan nama-nama hamba dan sifat-sifatnya dalam hal lafaz dan maknanya, akan tetapi hakikat Allah sebagai Khalik dan sifat-sifat-Nya itu sama sekali tidaklah sama dengan hakikat makhluk dan sifat-sifatnya. Para ulama sangat memahami makna lafaz-lafaz tersebut dan dapat membeda-bedakannya. Namun hakikat takwil yang sebenarnya hanya diketahui oleh Allah saja. ${ }^{21}$

${ }^{21}$ Manna' Khalil Al-Qattan, Studi Ilmu-Ilmu Qur'an..., hal. 310. 
Itulah sebabanya ketika kepada Malik dan ulama salaf lainnya ditanyakan tentang makna istiwa' (bersemayam) dalam firman Allah tersebut, mereka menjawab: "Maksud istiwa' (bersemayam) telah kita ketahui, namun mengenai bagaimana caranya bersemayam kita tidak mengetahuinya. Iman kepadanya adalah wajib dan menanyakannya adalah bid'ah."22

Demikian juga ayat-ayat mutasyabihat terkait berita-berita dari Allah tentang hari kemudian yang didalamnya terdapat lafaz-lafaz yang maknanya serupa dengan apa yang kita kenal, akan tetapi pada hakikatnya tidaklah sama. Misalnya di akhirat terdapat mizan (timbangan), jannah (taman), dan nar (api). Dan didalam syurga itu terdapat "sungai-sungai air yang rasa dan baunya tidak berubah, didalamnya ada tahta-tahta yang ditinggikan, gelas-gelas yang terletak (didekatnya), dan bantal-bantal sandaran yang tersusun dan permadani-permadani yang terhampar." (al-Gasyiyah [88]; 13-16. ${ }^{23}$

Berita-berita tersebut harus kita yakini dan imani disamping juga harus diyakini bahwa yang gaib itu lebih besar dari pada yang nyata, dan segala yang ada di akhirat adalah berbeda dengan apa yang ada di dunia. Namun hakikat perbedaan itu tidak diketahui manusia karena termasuk takwil yang hanya diketahui oleh Allah. ${ }^{24}$

Sebagian besar ulama mutakhirin menakwilkan ayat mutasyabih yang terkait dengan sifat Allah dengan tujuan untuk lebih memahasucikan Allah Swt. dari keserupaan-Nya dengan makhluk seperti yang mereka sangka. Hal tersebut dianganggap sebagai upaya penakwilan yang keliru dan bathil karena dapat menjatuhkan mereka kedalam kekhawatiran yang sama dengan apa yang mereka takuti atau bahkan lebih dari itu, misalnya ketika menakwilkan "tangan Allah" (yadullab) dengan "kekuasaan Allah" (qudrah Allah). Maksud mereka baik yaitu untuk menghindarkan penetapan "tangan” bagi Khalik 
agar tidak diserupakan dengan tangan makhluk mengingat makhluk juga memiliki tangan. Oleh karena lafaz tangan al-yad bagi mereka menimbulkan kekaburan, maka ditakwilkanlah dengan kekuasaan (alqudrab). Hal semacam ini tentu mengandung kontradiksi, karena hal itu berarti memaksa mereka untuk menetapkan sesuatu makna yang serupa dengan makna yang mereka sangka harus ditiadakan, karena makhluk pun mempunyai kekuasaan (al-qudrah) pula. Apabila qudrah yang mereka tetapkan itu betul dan mungkin, maka penetapan tangan bagi Allah pun betul dan mungkin. Sebaliknya jika penetapan "tangan" dianggap bathil dan terlarang karena menimbulkan keserupaan menurut dugaan mereka, maka penetapan "kekuasaan" juga bathil dan terlarang. Dengan demikian maka belum dapat dikatakan bahwa lafaz "yad" ini telah ditakwilkan, dalam arti dipalingkan dari makna yang rajih (kuat) kepada makna yang marjuh (lemah). ${ }^{25}$

D. Perbedaan Pendapat Para Ulama Terhadap Ayat-Ayat Mutasyabihat

Dalam pengertian secara umum sebagaimana disebutkan diatas, muhkam dan mutasyabih tidak menyisakan persoalan di kalangan ulama. Tapi ketika term muhkam dan mutasyabih ini dilihat dari pengertiannya secara khusus (terminologi) maka para ulama mulai membahas dan memperdebatkannya. Pengertian muhkam dan mutasyabih secara khusus ini mulai diperdebatkan ketika mereka menafsirkan firman Allah SWT yang artinya: ${ }^{26}$

“Dialah yang menurunkan Al-Kitab Al-Qur'an kepada kamu. Diantara (isi)-nya ada ayat-ayat yang muhkamat, itulah pokok-pokok Al-Qur'an dan yang lain ayatayat mutasyabihat. Adapun orang-orang yang dalam hatinya condong kepada kesesatan,maka mereka mengikuti sebagian ayat-ayat yang mutasyabihat daripadanya untuk menimbulkan fitnah untukmencari-cari takwilnya, padahal tidak ada yang mengetahui takwilnya melainkan Allah, dan orang -orang yang mendalam ilmunya berkata "kami beriman kepada ayat-ayat yang mutasyabihat

${ }^{25}$ Manna' Khalil Al-Qattan, Studi Ilmu-Imu Qur'an..., hal. 311.

26 Anshori, Ulumul Qur'an, (Jakarta: Raja Grafindo Persada, 2013), hal. 136. 
semuanya itu dari sisi tuhan kami." Dan tidak dapat mengambil pelajaran (daripadanya) melainkan orang-orang yang berakal.” (QS.Ali Imran[3]:7)

Selanjutnya, terkait masalah ayat-ayat yang muhkam dan mutasyabih ini terdapat 3 pendapat yaitu: ${ }^{27}$

Pendapat pertama menyatakan bahwa Al-Qur'an seluruhnya adalah muhkam, mengingat Firman Allah SWT :

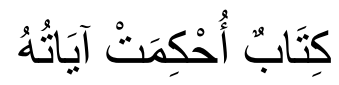

Artinya: "Suatu Kitab yang dijelaskan (uhkimat) ayat-ayatnya" (QS. Hud: 1).

Pendapat kedua menyatakan bahwa Al-Qur'an seluruhnya adalah mutasyabih, mengingat firman Allah SWT:

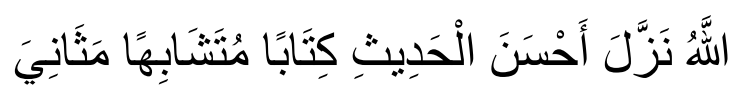

Artinya : "Allah telah menurunkan perkataan yang paling baik (yaitu) Al-Qur'an yang serupa (mutu ayat-ayatnya) lagi berulang-ulang,ulang” (QS. Az-Zumar: 23).

Pendapat ketiga dan yang paling kuat menyatakan bahwa Al-Qur'an ada yang muhkam dan ada pula yang mutasyabih dengan beralasan kedua ayat tersebut di atas. Sebab, maksud "ubkimat ayatubu" dalam ayat tersebut di atas menjelaskan tentang kesempurnaan Al-Qur'an dan tidak adanya pertentangan antar ayat-ayatnya. Sedangkan maksud mutasyabih dalam ayat di atas menerangkan segi kesamaannya dalam kebenaran, kebaikan dan kemu’jizatan.

Selanjutnya, bila ditinjau dari sisi jangkauan pengetahuan manusia terhadap maknanya, Abud Djalal membagi ayat-ayat mutasyabih tiga yaitu sebagai berikut :

1. Ayat-ayat mutasyabihat yang tidak dapat diketahui oleh seluruh umat manusia, kecuali Allah SWT. Contoh : Artinya : "Dan pada sisi Allah-lah kunci-kunci semua yang ghaib, tak ada yang mengetahuinya, kecuali Dia sendiri”. (Q.S. Al-An'am : 59)

2. Ayat-ayat mutasyabihat yang dapat diketahui oleh semua orang dengan jalan pembahasan dan pengkajian yang mendalam. Contoh : pencirian mujmal, menentukan musytarak, mengqayyidkan yang mutlak, menertibkan yang kurang tertib, dst.

${ }^{27}$ Abdul Djalal, Ulumul Qur'an..., hal. 256-258. 
3. Ayat -ayat mutasyabihat yang tidak semua orang dapat mengetahuinya, atau hanya dapat diketahui oleh para pakar ilmu dan sains tertentu saja. Hal ini termasuk urusan - urusan yang hanya diketahui Allah SWT dan orang-orang yang rosikh (mendalam) ilmu pengetahuannya. ${ }^{28}$

Adapun sikap para ulama terhadap ayat-ayat mutasyabih terbagi menjadi 2 kelompok, yaitu:

Pertama: Madzhab Salaf, salah satu diantara para ulama yang masuk ke dalam kelompok ini adalah Imam Malik yang berasal dari ulama terdahulu (mutaqaddimin). Para ulama pada kelompok ini mengambil sikap kehati-hatian sebagai bentuk penjagaan diri dari kesalahan yang mungkin dapat terjadi dengan berdasar pada menyucikan Allah dari pengertian-penegertian lahir yang mustahil bagi Allah dan mengimaninya sebagaimana yang diterangkan Al-Qur'an sehingga mereka lebih mempercayai dan mengimani ayat-ayat mutasyabih dan menyerahkan sepenuhnya langsung kepada Allah Swt. ${ }^{29}$

Kedua: Madzhab Khalaf, salah satu yang termasuk ke dalam kelompok ini yaitu ulama muataakhirin (modern) dimana mereka mentakwil ayat-ayat mutasyabihat secara terperinci dengan menentukan makna-maknanya berdasarkan penggunaan kata tersebut yang sesuai dengan lahirnya (zhahir). Metode ini diambil atas dasar kekhawatian mereka akan terjadinya goncangan terhadap keyakinan orang terutama mereka yang awam sehingga terjaga dari tasybih (menyerupakan Allah dengan makhluk-Nya). ${ }^{30}$

Suatu hal yang seyogyanya dilakukan dalam hal memahami ayat-ayat mutasyabihat itu adalah memalingkan lafal dari keadaan kehampaan yang mengakibatkan kebingungan manusia, sehingga tidak membiarkan lafal itu “terlantar" tidak bermakna. Selama ayat-ayat tersebut memungkinkan untuk dilakukan pentakwilan terhadapnya dengan makna yang benar dan rasional, maka tidak ada halangan bagi nalar manusia dalam hal ini bagi mereka yang sudah memiliki ilmu yang mendalam dan kemampuan tinggi. ${ }^{31}$

\footnotetext{
${ }^{28}$ Abdul Djalal, Ulumul Qur'an..., hal. 251-252.

${ }^{29}$ Usman, Ulumul Qur'an, (Yogyakarta: Teras, 2009), hal. 244.

${ }^{30}$ Rosihon Anwar, Ulum Al-Qur'an..., hal. 127-128.

${ }^{31}$ Usman, Ulumul Qur'an..., hal. 245.
} 
Berdasarkan hal tersebut, setidaknya dua pendapat di atas telah mewakili masing-masing kelompok yang setuju apakah sebaiknya ayat-ayat mutasyabihat itu ditakwilkan atau tidak. Keduanya pun sama-sama memiliki alasan yang kuat untuk mempertahankan pendapatnya. Meski demikian, penulis cenderung memilih pendapat yang kedua, yang setuju bahwa ayat-ayat mutasyabihat perlu ditakwilkan untuk mengetahui makna yang tersembunyi di dalamnya. Hal ini karena zaman yang selalu berubah sehingga menakwilkan suatu ayat yang masih samar maknanya merupakan sebuah kebutuhan. Namun, terlepas dari itu semua, ada hikmah dan nilai-nilai pendidikan yang dapat diambil dari keberadaan ayatayat muhkamat dan Mutasyabihat dalam al- Qur'an.

E. Hikmah dan Nilai-Nilai Pendidikan dalam Muhkam-Mutasyabih Al-Qur'an

Al-Qur'an berfungsi sebagai bayan (penjelas) dan hudan (petunjuk) dimana didalamnya memuat ayat yang tersurat atau muhkam. Selain itu, al-Qur'an juga berfungsi sebagai mukjizat dan kitab sastra terbesar sepanjang sejarah manusia dimana didalamnya memuat ayat yang tersirat atau mutasyabih yang tidak akan habis-habisnya untuk dikaji dan diteliti. Ayat-ayat muhkamat dan mutasyabihat adalah dua hal yang saling melengkapi dalam al-Qur'an. ${ }^{32}$

Dari sini, dapat disimpulkan setidaknya ada tiga hikmah yang dapat diambil dari persoalan muhkam dan mutasyabih tersebut, hikmah-hikmah itu adalah: Pertama, Andaikata seluruh ayat al-Qur'an terdiri dari ayat-ayat muhkamat, niscaya akan sirnalah ujian keimanan dan amal lantaran pengertian ayat yang jelas. Kedua, Seandainya seluruh ayat al-Qur'an mutasyabihat, niscaya akan lenyaplah kedudukannya sebagai penjelas dan petunjuk bagi manusia. Orang yang benar keimanannya yakin bahwa al-Qur'an seluruhnya dari sisi Allah, segala yang datang dari sisi Allah pasti hak dan tidak mungkin bercampur dengan kebatilan. Seperti dalam firman-Nya: ${ }^{33}$

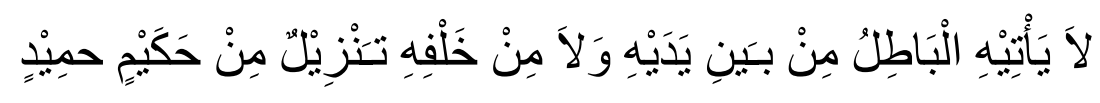

32 Siti Badiah, Hikmah dan Nilai-Nilai Pendidikan Adanya Ayat-Ayat Mubkamat dan Mutasyabihat dalam Al-Qur'an, Al-Dzikra Vol.XI No. 1, Januari-Juni 2017, hal. 120.

${ }_{3}$ Muhammad Chirzin, Al-Qur'an dan Ulumul Qur'an..., hal 74-75. 
Artinya: Tidak akan datang kepadanya (al-Qur'an) kebatilan, baik dari depan maupun dari belakang, yang diturunkan dari Tuhan yang Maha Bijaksana lagi Maha Bijaksana lagi Maha Terpuji. (Q.S. Fussilat [41]: 42).

Ketiga, dengan adanya ayat-ayat yang muhkamat dan ayat-ayat mutasyabihat dalam al-Qur'an, tentunya menjadikan umat Islam terus termotivasi untuk menggali berbagai kandungannya yaitu bersedia membaca al-Qur'an dengan khusyu' sambil merenung dan berpikir sehingga mereka akan terhindar dari taklid.

Selain itu, dengan dikelompokkannya ayat-ayat al-Qur'an ke dalam kategori muhkamat dan mutasyabihat ini manusia dapat belajar bagaimana Allah telah menjadikan al-Qur'an sedemikian rupa untuk dipelajari dan dijadikan sebagai pedoman hidup. Melalui ayat-ayat muhkam dan mutasyabih, umat Islam dituntut untuk lebih kritis lagi dalam memahami dan menafsirkan ayat-ayat yang tedapat dalam al-Qur'an. Dan ini terbukti dengan banyaknya ulama yang telah membahas tentang muhkam dan mutasyabih, baik dari segi definisi yang berbedabeda, keberadaan ayat-ayatnya dalam al-Qur'an serta kriteria dan pembagiannya, hingga kontroversi seputar boleh dan tidaknya melakukan pentakwilan tehadap ayat-ayat yang mutasyabihat. ${ }^{34}$

Demikianlah mereka berargumen untuk membenarkan pendapat mereka masing-masing. Masing-masing dari mereka tentunya sama-sama mempunyai dalil yang kuat. Maka, sebagai umat Islam kita hendaknya menghargai setiap pendapat yang ada, meskipun kita pada akhirnya dituntut untuk memilih salah satu yang paling kuat dan relevan untuk saat ini. Meskipun dalam hal ini penulis cenderung memilih pendapat yang menyetujui bahwa ayat-ayat mutasyabihat dapat ditakwilkan, bukan berarti penulis mengabaikan kalangan yang menolaknya. Itulah hikmah terbesar dari dijadikannya al-Qur'an dalam bentuk muhkam dan mutasyabih.

Ketika hikmah ini kita kaitkan dengan dunia pendidikan, setidaknya Allah telah mengajarkan tentang bagaimana cara menyikapi perbedaan yang terjadi dengan bijaksana yaitu dengan saling menghargai seperti ajaran melalui muhkam

34 Siti Badiah, Hikmah dan Nilai-Nilai Pendidikan..., hal. 121. 
dan mutasyabih dimana terdapat perbedaan pendapat dari para ulama dalam menyikapinya namun bisa saling menghargai setiap pendapat tersebut dengan tidak saling memusuhi. Justru dengan perbedaan pendapat yang ada, mereka saling menguatkan dan melengkapi antara yang satu dengan lainnya. Sebab, tidak dapat dipungkiri bahwa setiap dari kita pastinya memiliki perbedaan antara yang satu dengan lainnya.

Tidak hanya itu, dengan adanya muhkam dan mutasyabih dalam alQur'an, umat Islam dituntut untuk semakin kritis dalam memahami maksud Tuhan yang tersembunyi dibalik ayat-ayatnya. Dengan begitu, manusia akan memaksimalkan anugrah terbesar yang telah Tuhan berikan kepadanya, yaitu akal untuk berfikir.

Selain hikmah tersebut diatas, adapun hikmah adanya ayat-ayat muhkam dan mutasyabihat secara umum adalah sebagai beikut:

1. Hikmah Ayat-Ayat Muhkamat

a. Menjadi rahmat bagi manusia. Dengan adanya ayat-ayat muhkam yang sudah jelas arti maksudnya, sangat berarti besar bagi mereka, khususnya yang kemampuan bahasa Arabnya lemah.

b. Memudahkan bagi manusia mengetahui dan menghayati arti dan maksudnya sehingga umat mudah mengamalkan pelaksanaan ajaran-ajarannya.

c. Menghilangkan kesulitan dan kebingungan umat dalam mempelajari isi ajarannya, karena lafal ayat-ayat sudah dapat menjelaskan arti yang dimaksud dengan sendirinya, tidak harus menuggu penafsiran atau penjelasan dari lafal / ayat / surah yang lain. ${ }^{35}$

2. Hikmah Ayat-Ayat Mutasyabihat

a. Memperlihatkan kelemahan akal manusia. Sebagaimana Allah memberi cobaan pada badan untuk beribadah, akal juga dicoba untuk meyakini keberadaan ayat-ayat mutasyabih agar seseorang

35 Abdul Djalal, Ulumul Qur'an..., hal. 262-263. 
yang berpengetahuan tinggi terhindar dari menyombongkan keilmuannya sehingga ia tunduk kepada naluri kehambaannya.

b. Melalui pengalaman indrawi yang biasa disaksikan, manusia menerima pemahaman abstrak-ilahiah sebagaimana diketahui bahwa pemahaman diperoleh manusia tatkala ia diberi gambaran indrawi terlebih dahulu. Dalam kasus sifat-sifat Allah, Allah memberikan gambaran fisik agar manusia dapat lebih mengenal sifat-sifat-Nya. Bersamaan dengan itu, Allah menegaskan bahwa dalam hal kepemilikan anggota badan, diri-Nya tidaklah sama dengan hamba-Nya. ${ }^{36}$

c. Agar dapat mengerti terjemahannya, menghayati maksudnya, mau tidak mau umat manusia harus giat mempelajari ayat mutasyabihat dalam Al-Qur'an sehingga dapat mempedomani isi ajarannya. Hal tersebut berarti menjadikan umat terus termotivasi untuk giat belajar, tekun menalar, dan rajin meneliti.

d. Memperlihatkan kemukjizatan Al-Quran, ketinggian mutu sastra dan balaghahnya, agar manusia menyadari sepenuhnya bahwa kitab itu bukanlah buatan manusia biasa, melainkan wahyu ciptaan Allah SWT.

e. Mendorong kegiatan mempelajari disiplin ilmu pengetahuan yang bermacam-macam. Sebab, orang-orang yang akan memperlajari ayat-ayat mutasyabihat dalam Al-Qur'an harus mempelajari beberapa disiplin ilmu lain yang terkait dengan berbagai isi ajaran Al-Qur'an yang bermacam-macam. ${ }^{37}$

${ }^{36}$ Rosihon Anwar, Ulum Al-Qur'an..., hal. 135.

37 Abdul Djalal, Ulumul Qur'an..., hal. 265-266. 


\section{KESIMPULAN}

Dari pengertian diatas, dapat disimpulkan bahwa muhkam adalah ayat-ayat yang maknanya sudah jelas, tidak samar lagi. Adapun mutasyabih adalah ayat-ayat yang maknanya belum jelas sehingga memerlukan pentakwilan untuk mengetahui maksudnya. Al-Qur'an berfungsi sebagai bayan (penjelas) dan hudan (petunjuk) dimana didalamnya memuat ayat yang tersurat atau muhkam. Selain itu, al-Qur'an juga berfungsi sebagai mukjizat dan kitab sastra terbesar sepanjang sejarah manusia dimana didalamnya memuat ayat yang tersirat atau mutasyabih yang tidak akan habishabisnya untuk dikaji dan diteliti. Ayat-ayat muhkamat dan mutasyabihat adalah dua hal yang saling melengkapi dalam al-Qur'an.

Namun demikian, terdapat perbedaan pendapat di kalangan umat Islam terkait pentakwilan tersebut, dimana tidak semuanya sepakat mengenai kebolehan menafsirkan ayat-ayat yang mutasyabihat tersebut atau dengan kata lain melarangnya. Namun, dibalik kontroversi yang timbul akibat perbedaan pendapat tersebut, justru mengantarkan pada pemahaman terkait hikmah yang dapat dipetik pelajarannya dalam kehidupan manusia.

Ketika hikmah ini kita kaitkan dengan dunia pendidikan, setidaknya Allah telah mengajarkan tentang bagaimana cara menyikapi perbedaan yang terjadi dengan bijaksana yaitu dengan saling menghargai seperti ajaran melalui muhkam dan mutasyabih dimana terdapat perbedaan pendapat dari para ulama dalam menyikapinya namun bisa saling menghargai setiap pendapat tersebut dengan tidak saling memusuhi. Justru dengan perbedaan pendapat yang ada, mereka saling menguatkan dan melengkapi antara yang satu dengan lainnya. Sebab, tidak dapat dipungkiri bahwa setiap dari kita pastinya memiliki perbedaan antara yang satu dengan lainnya.

Tidak hanya itu, dengan adanya muhkam dan Mutasyabih dalam al-Qur'an, umat Islam dituntut untuk semakin kritis dalam memahami maksud Tuhan yang bersembunyi dibalik ayat-ayatnya. Dengan begitu, manusia akan memaksimalkan anugrah terbesar yang telah Tuhan berikan kepadanya, yaitu akal untuk berfikir. 


\section{DAFTAR PUSTAKA}

Anshori, Ulumul Qur'an, Jakarta: Raja Grafindo Persada, 2013.

Al-Qattan, Manna' Khalil, Studi Ilmu-Imu Qur'an; diterjemahkan dari bahasa Arab oleh Mudzakir, Jakarta: PT Pustaka Litera Antar Nusa, 2009.

Anwar, Rosihon, Ulum Al-Qur'an, Bandung: CV Pustaka Setia, 2007.

Badiah, Siti, Hikmah dan Nilai-Nilai Pendidikan Adanya Ayat-Ayat Mubkamat dan Mutasyabibat dalam Al-Qur'an, Al-Dzikra Vol. XI No. 1, Januari-Juni 2017.

Chirzin, Muhammad, Al-Qur'an dan Ulumul Qur'an, Yogyakata: PT Dana Bhakti Prima Yasa, 1998.

Departemen Agama RI, Al-Qur'an dan Terjemahnya, Bandung: Alfatih, 2012.

Djalal, Abdul, Ulumul Qur'an, Surabaya: Dunia Ilmu, 2000.

Nahar, Syamsu, Keberadaan Ayat Mubkam dan Mutasyabih dalam Al-Qur'an, Nizhamiyah, Vol. VI, No.2, Juli-Desember 2016.

Usman, Ulumul Qur'an, Yogyakarta: Teras, 2009.

Wahid, Ramli Abdul, Ulumul Qur'an, Jakarta: PT. Grafindo Raja Persada: Jakarta,1994

Zed, Mestika, Metode Penelitian Kepustakaan, Jakarta: Yayasan Obor Indonesia, 2008 